\title{
A Pictogram on Pharmacological Management of Corona Viral Infection: What are the Available Options?
}

\author{
Arun HS Kumar*
}

\section{BACKGROUND}

Corona virus are known to infect the respiratory and enteric system resulting in benign to several pathological outcomes. ${ }^{1,2}$ The human coronaviruses typically lead to upper respiratory tract infections resulting in the general common cold symptoms. In contrast the coronaviruses which have zoonotic origin result in more severe to fatal disease manifestations. ${ }^{1,2}$ Coronaviruses have an incubation period of 2-6 days before manifesting non-specific symptoms such as fever, tiredness, cough, dyspnoea, myalgia or fatigue, sore throat, rhinorrhoea and diarrhoea. Biochemically elevated aspartate Aminotransferase (AST), Alanine Aminotransferase (ALT), serum ferritin and C-reactive protein above the upper limit of the reference range is reported. ${ }^{1,2}$

Despite the health threat from Corona virus infections, currently there are no effective vaccines or antiviral agents available for clinical use. Nevertheless, the antiviral agents Figure 1 especially of the Protease inhibitors category Figure 2 developed to treat other viral infections seems to have therapeutic efficacy against the Corona viruses. ${ }^{3-5}$ Hence this study overviews the available antiviral drugs as possible options to treat Corona virus infection Figure 3.

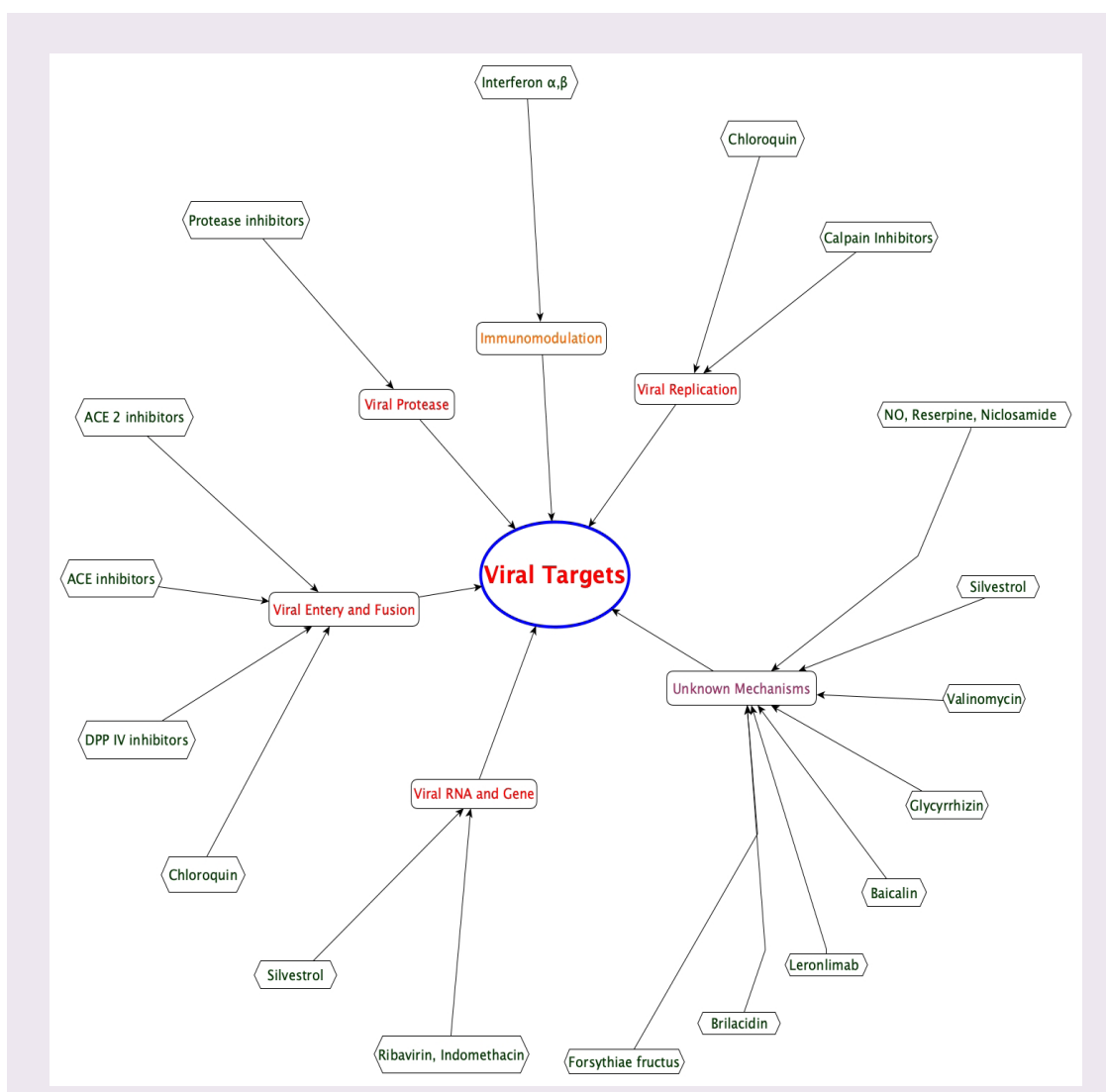

Figure 1: The potential viral targets. 


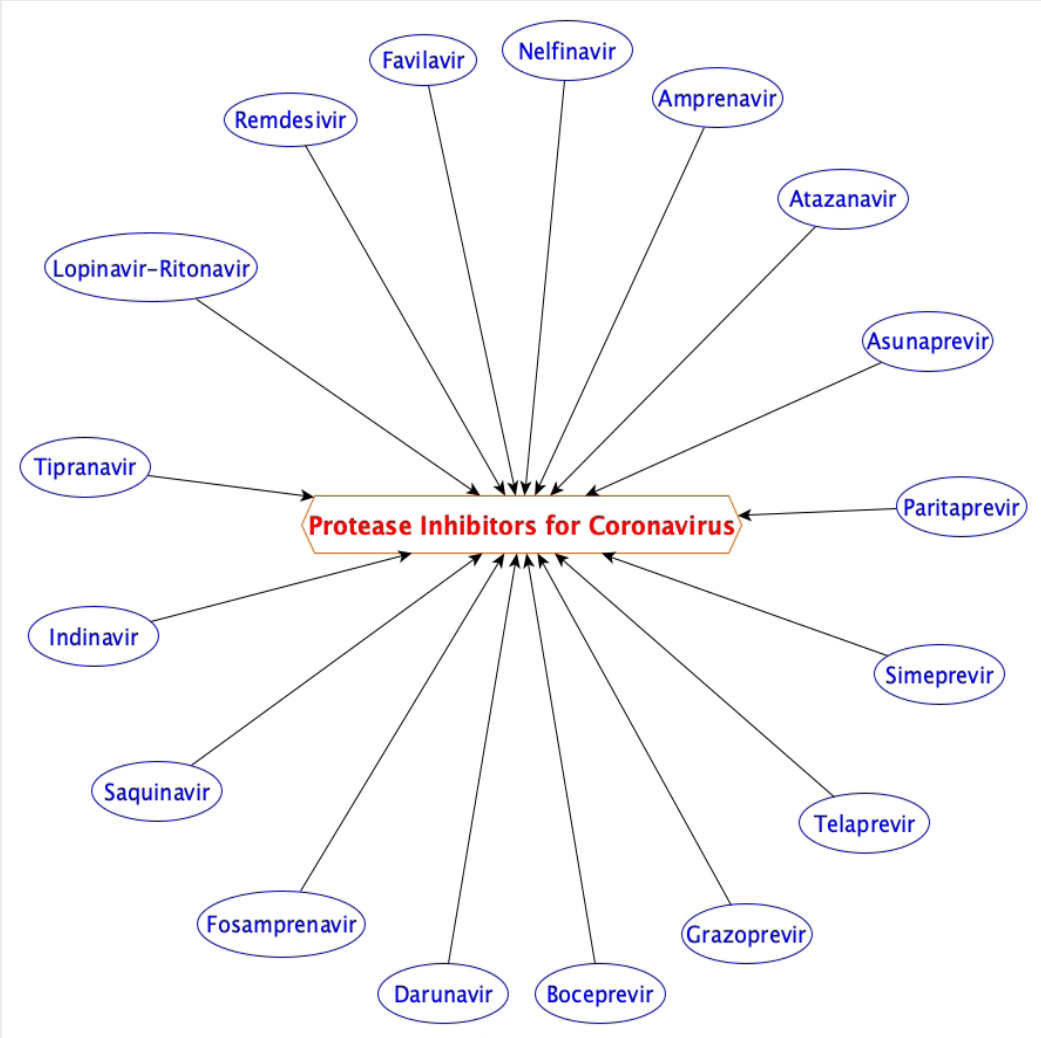

Figure 2: The pharmacological inhibitors of viral proteases (Protease inhibitors).

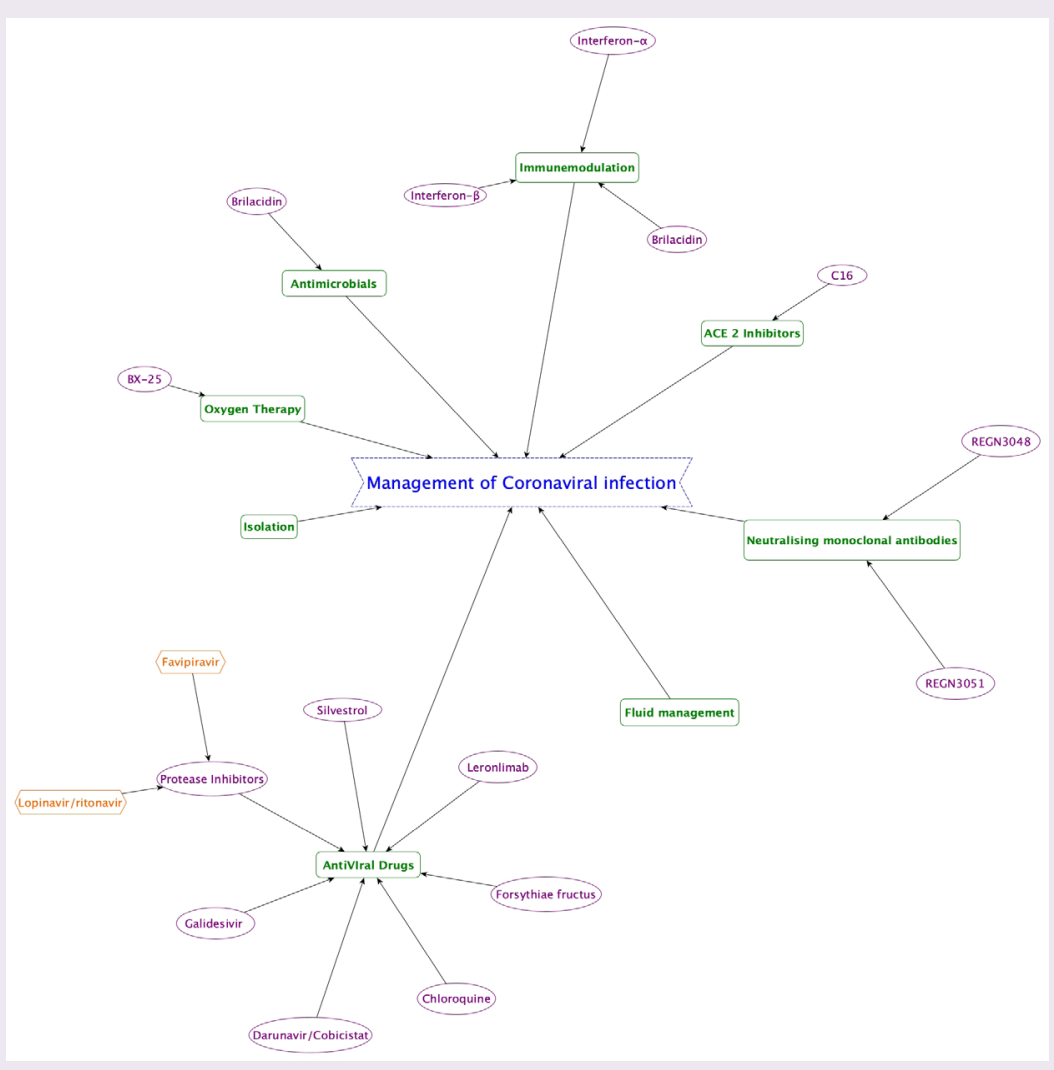

Figure 3: Clinical management of coronaviral infection. 


\section{ACKNOWLEDGEMENT}

Research support from University College Dublin-Seed funding/Output Based Research Support Scheme (AHSK), Royal Society-UK (AHSK) and Stemcology (AHSK) is acknowledged.

\section{REFERENCES}

1. Li Q, et al. Early Transmission Dynamics in Wuhan, China, of Novel CoronavirusInfected Pneumonia. N Engl J Med. 2020;1:1-9
2. Habibzadeh P, Stoneman EK. The Novel Coronavirus: A Bird's Eye View. Int J Occup Environ Med. 2020;11(2)65-71.

3. Piras S, et al. Dichloro-Phenyl-Benzotriazoles: A New Selective Class of Human Respiratory Syncytial Virus Entry Inhibitors. Front Chem. 2019;7:247.

4. Muller $\mathrm{C}$, et al. Broad-spectrum antiviral activity of the elF4A inhibitor silvestrol against corona and picornaviruses. Antiviral Res. 2018;150:123-9.

5. Elgner $F$, et al. Inhibition of Zika Virus Replication by Silvestrol. Viruses. 2018;10(4):149.

Cite this article : Kumar AHS. A Pictogram on Pharmacological Management of Corona Viral Infection: What are the Available Options?. BEMS Reports. 2019;5(2):17-9. 